Jurnal UJMC, Volume 6, Nomor 1, Hal. 25 - 32

pISSN : 2460-3333 eISSN : 2579-907X

\title{
Analisis Data Produksi Ikan Konsumsi Menggunakan Uji Friedman
}

\author{
Emy Natun Na'imah ${ }^{1}$, Siti Alfiatur Rohmaniah ${ }^{2}$ \\ ${ }^{1}$ Universitas Islam Darul Ulum Lamongan, emynatun@gmail.com \\ ${ }^{1}$ Universitas Islam Darul Ulum Lamongan, nia0304@gmail.com
}

\begin{abstract}
Agriculture in Lamongan district is known as minipadi. This is because the majority of rice fields in Lamongan district can also be used for fisheries. It is appropriate that the development of the agriculture and fisheries sectors receive special attention and the results can be seen as one of the keys to the success of the government in realizing people's welfare. The purpose of this study was to determine the descriptive data analysis of fish production in Lamongan district with the Friedman test. From the maximum value of production, the sector that is most superior in consumption fish production is pond cultivation, and the lowest is floating net cage cultivation. The districts with the most potential in consumption fish production are Glagah, Karamgbinangun and Turi Districts.
\end{abstract}

Keywords: Fisheries, Uji Friedman, Lamongan district

\begin{abstract}
Abstrak. Pertanian di kabupaten Lamongan terkenal dengan istilah minipadi. Hal itu dikarenakan mayoritas lahan sawah di kabupaten Lamongan dapat pula digunakan untuk lahan perikanan. Sudah selayaknya pembangunan sektor pertanian maupun perikanan mendapat perhatian khusus dan hasilnya dapat dipandang sebagai salah satu kunci sukses pemerintah dalam mewujudkan kesejahteraan masyarakat. Tujuan penelitian ini adalah untuk mengetahui analisis data deskriptif produksi ikan di kabupaten Lamongan dengan Uji Friedman. Dari nilai maksimum hasil produksi sektor yang paling unggul dalam produksi ikan konsumsi yakni budidaya kolam, dan yang terendah adalah budidaya keramba jaring apung. Kecamatan terpotensial dalam produksi ikan konsumsi, yaitu Kecamatan Glagah, Karamgbinangun dan Turi.
\end{abstract}

Kata Kunci: Perikanan, Uji Friedman, Kabupaten Lamongan

\section{Latar Belakang}

Pertanian di kabupaten Lamongan terkenal dengan istilah minipadi. Hal itu dikarenakan mayoritas lahan sawah di kabupaten Lamongan dapat pula digunakan untuk lahan perikanan. Sebagai daerah yang mempunyai potensi besar pertanian maupun perikanan, sudah selayaknya pembangunan sektor pertanian maupun perikanan mendapat perhatian khusus dan hasilnya dapat dipandang sebagai salah satu kunci sukses pemerintah dalam mewujudkan kesejahteraan masyarakat [1].

Perikanan merupakan salah satu kegiatan usaha dari subsektor pertanian yang memiliki peran sangat penting di kabupaten Lamongan. Menurut [2], sub sektor perikanan di kabupaten Lamongan memiliki kenaikan nilai tukar petani tertinggi pada tahun 2019, sehingga diharapkan pemerintah lebih memperhatikan sub sektor pertanian dengan berbagai cara. 
Data statistik perikanan dibedakan atas data perikanan tangkap dan perikanan budidaya. Perikanan tangkap diklasifikasikan atas penangkapan ikan laut dan penangkapan ikan diperairan umum. Perikanan budidaya diklasifikasikan atas jenis budidaya yaitu budidaya laut, tambak, kolam, karamba, jaring apung, dan sawah. Rumah tangga perikanan tangkap adalah rumah tangga yang melakukan kegiatan penangkapan ikan atau binatang air lainnya atau tanaman air dengan tujuan Sebagian atau seluruh hasilnya untuk dijual. Rumah tangga perikanan budidaya adalah rumah tangga yang melakukan kegiatan budidaya ikan atau binatang air lainnya atau tanaman air dengan tujuan sebagian/seluruh hasilnya dijual [3].

Tujuan penelitian ini adalah untuk mengetahui analisis data deskriptif produksi ikan di kabupaten Lamongan dengan Uji Friedman dan menemukan budidaya ikan konsumsi yang potensial di kabupaten Lamongan. Hasil dari penelitian ini juga diharapkan dapat digunakan untuk mengambil tindakan bagaimana cara meningkatkan produksi ikan konsumsi di kabupaten Lamongan.

\section{Metode Penelitian}

\subsection{Statistika Inferensial}

Dalam penelitian ini menggunakan kombinasi dari dua analisis yaitu analisis korelasional dan analisis komparasi.

1) Analisis Korelasional

Analisis ini merupakan analisis statistik yang digunakan untuk mencari hubungan atau pengaruh antara dua buah variabel atau lebih. Koefesien korelasi adalah suatu ukuran arah dan kekuatan hubungan linier antara dua variabel random (Watson \& Craft, 624). Yang dimaksud pengukuran secara linier adalah pengukuran atau perhitungan korelasi yang hanya melibatkan satu variabel prediktor dan satu variabel respon, ataupun antar sesama variabel prediktor (Sunyoto, 2009). Koefisien korelasi dinotasikan dengan r. Koefisien korelasi bertanda + (positif) atau - (negatif), dengan angka berkisar dari -1 hingga +1 [4]. Semakin mendekati +1 , koefisien korelasi menunjukkan adanya hubungan yang positif dan kuat. Apabila koefisien korelasi yang mendekati -1 menunjukkan hubungan yang negatif dan kuat. Jika koefisien korelasi mendekati 0, memberikan indikasi bahwa kedua variabel tidak memiliki hubungan. Salah satu rumus koefisien korelasi menurut Carl Pearson, yaitu:

$$
r=\frac{n \sum_{i=1}^{n} X_{i} Y_{i}-\left(\sum_{i=1}^{n} X_{i}\right)\left(\sum_{i=1}^{n} Y_{i}\right)}{\sqrt{n \sum_{i=1}^{n} X_{i}^{2}-\left(\sum_{i=1}^{n} X_{i}\right)^{2}} \sqrt{n \sum_{i=1}^{n} Y_{i}^{2}-\left(\sum_{i=1}^{n} Y_{i}\right)^{2}}}
$$

Jika dua variabel berkorelasi positif, maka kenaikan variabel satu akan diikuti kenaikan variabel lain dan penurunan variabel satu diikuti dengan penurunan variabel lain. Sedangkan korelasi negatif menunjukkan apabila satu variabel naik, variabel lain akan turun. Untuk memudahkan interpretasi mengenai kekuatan hubungan antara dua variabel ada beberapa kriteria [5]: 0 : Tidak ada korelasi ; <0,5 : Korelasi lemah; 0,5 - <0,75 : Korelasi cukup kuat ; $0,75-<0,9$ : Korelasi kuat; $0,9-<1$ : Korelasi sangat kuat; 1 : Korelasi 
sempurna. Jika menggunakan software SPSS 16.0 bisa menggunakan uji spearman dalam menentukan pengaruh antar dua variabel.

2) Analisis Komparasi

Analisi Komperasi digunakan dalam penarikan kesimpulan dan pembuatan keputusn data perikanan yang ada di kabupaten lamongan dari tahun 2013 sampai tahun 2017. Analisis komparasi adalah teknik analisis statistik yang bertujuan untuk membandingkan antara kondisi dua buah kelompok atau lebih. Teknik analisis yang digunakan juga cukup banyak, penggunaan teknik analisis tersebut tergantung pada jenis skala data dan banyak sedikitnya kelompok. Jenis-jenis analisis komparasi dapat dilihat pada tabel 1. berikut.

Tabel 1. Analisis Komparasi

\begin{tabular}{|c|c|c|c|c|}
\hline \multirow{2}{*}{\multicolumn{2}{|c|}{$\begin{array}{c}\text { Jumlah } \\
\text { Kelompok }\end{array}$}} & \multicolumn{3}{|c|}{ Variabel yang diuji } \\
\hline & & \multirow{2}{*}{$\begin{array}{l}\quad \text { Nominal } \\
\text { - Kai Kuadrat } \\
\text { - Kolmogorov- } \\
\text { Smirnov }\end{array}$} & \multirow{2}{*}{\begin{tabular}{|l}
\multicolumn{1}{|c}{ Ordinal } \\
- Mann-Whitney U \\
- Kolmogorov- \\
Smirnov \\
- Kai Kuadrat
\end{tabular}} & \multirow{2}{*}{$\begin{aligned} & \text { Interval } \\
& \text { - Separate } t \text {-test } \\
& \text { - Pooled t-test }\end{aligned}$} \\
\hline N & $\begin{array}{l}\text { 㝘 } \\
\frac{90}{0} \\
\frac{9}{0} \\
\frac{9}{3}\end{array}$ & & & \\
\hline 䯧 & $\frac{8}{\frac{8}{7}}$ & & $\begin{array}{l}\text { - Wilcoxon } \\
\text { - McNemar } \\
\text { - Sign Test }\end{array}$ & - Paired/corelated t-test \\
\hline \multirow{2}{*}{ 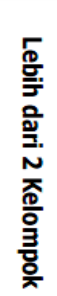 } & 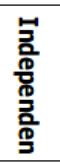 & $\begin{array}{l}\text { - Kai Kuadrat } \\
\text { - Kolmogorov- } \\
\text { Smirnov }\end{array}$ & $\begin{array}{l}\text { - Kruskall-Wallis } \\
\text { - Uji Median } \\
\text { - Kai Kuadrat }\end{array}$ & $\begin{array}{l}\text { - Analisis Varians } \\
\text { (ANAVA) }\end{array}$ \\
\hline & 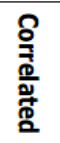 & & $\begin{array}{l}\text { - Friedman } \\
\text { - Kendall's W } \\
\text { - Cochran's Q }\end{array}$ & $\begin{array}{l}\text { - ANAVA repeat } \\
\text { measures }\end{array}$ \\
\hline
\end{tabular}

\subsection{Regresi Linear Non Parametrik}

Non Parametrik merupakan salah satu kelompok analisis statistik yang ditinjau dari bentuk parameternya. Yang mana ada dua kelompok yakni statistik parametrik dan nonparametrik. Statistik parametrik adalah analisis statistik yang pengujiannya menetapkan syarat-syarat tertentu tentang bentuk distribusi parameter atau populasinya, seperti data berskala interval dan berdistribusi normal. Sedangkan statistik nonparametrik adalah analisis statistik yang tidak menetapkan syarat-syarat tersebut. Dalam pengujian data perikanan kabupaten lamongan diambil dari data tahun 2013 sampai tahun 2017 kali ini menggunakan uji friedman, namun sebelum itu perlu dilakukan prosedur pengujian normalitas data terlebih dahulu.

\subsubsection{Uji Normalitas}

Uji normalitas berguna untuk menentukan data yang telah dikumpulkan berdistribusi normal atau diambil dari populasi normal. Uji statistik normalitas yang dapat digunakan diantaranya Chi-Square. Kesimpulan normal atau tidaknya suatu data didasarkan pada prinsip uji hipotesis yang berpatokan pada Ho dan Ha. Dalam hal ini, Ho berbunyi "Distribusi data sama dengan distribusi normal", Ha berbunyi "Distribusi data tidak sama dengan distribusi normal". Apabila nilai-p 
kurang dari alpha 0.05 (mis 0.000), maka Ho ditolak dan disimpulkan "Distribusi data adalah tidak normal". Sedangkan apabila nilai-p lebih dari atau sama dengan alpha 0.05 (mis. 0.222), maka Ho gagal ditolak dan disimpulkan "Distribusi data adalah normal"

$$
X^{2}=\sum \frac{\left(O_{i}-E_{i}\right.}{E_{i}}
$$

\subsubsection{Uji Friedman}

Uji Friedman dilakukan untuk mengetahui perbedaan lebih dari dua kelompok sampel yang saling berhubungan serta untuk menguji hipotesis komparatif $\mathrm{k}$ sampel berpasangan. Uji Friedman digunakan sebagai alternatif untuk menganalisis rancangan kelompok seperti halnya pada analisis untuk rancangan acak kelompok lengkap. Dengan mengasumsikan pengacakan perlakuan dilakukan pada blok selanjutnya pengukuran dirangking dalam kelompok. Tingkat signifikansi yang digunakan yaitu $\alpha=0,05$ dengan kriteria pengambilan keputusan $\mathrm{H}_{0}$ ditolak jika $\mathrm{X}^{2}$ hitung lebih dari atau sama dengan $\mathrm{X}^{2}$ tabel dan statistik uji:

$$
X^{2}=\frac{12}{N k(k+1)} \sum_{j=1}^{k}\left(R_{j}\right)^{2}-3 N(k+1)
$$

\section{Hasil dan Pembahasan}

\subsection{Analisis Data Deskriptif Perikanan kabupaten Lamongan}

Data diambil dari buku Badan Pusat Statistik (BPS) berjudul "Lamongan Dalam Angka 2018" dan "Lamongan Dalam Angka 2017" selama 5 tahun terakhir yakni data hasil produksi ikan konsumsi yang dimulai dari tahun 2013 sampai tahun 2017. Data tersebut meliputi perikanan tangkap diklasifikasikan atas penangkapan ikan laut dan penangkapan ikan diperairan umum. Perikanan Budidaya diklasifikasikan atas jenis budidaya yaitu budidaya keramba, kolam, sawah tambak, dan tambak. Dan produksi ikan konsumsi hasil perairan umum yaitu ikan konsumsi rawa, waduk, dan sungai.

Tabel 2. Data hasil produksi ikan konsumsi

\begin{tabular}{cccccccc}
\hline & Tambak & $\begin{array}{c}\text { Sawah } \\
\text { Tambak }\end{array}$ & Kolam & $\begin{array}{c}\text { Keramba } \\
\text { Jaring Apung }\end{array}$ & Rawa & Waduk & Sungai \\
\hline 2011 & 4.343 .267 & 31.206 .771 & 1.075 .256 & 0 & 979.411 & 885.011 & 1.117 .490 \\
2012 & 3.818 .581 & 32.263 .499 & 1.150 .296 & 0 & 943.930 & 9.899 .600 & 1.021 .700 \\
2013 & 3.591 .081 & 33.988 .694 & 9.975 .622 & 3470 & 903.200 & 1.069 .200 & 1.060 .600 \\
2014 & 3.972 .588 & 36.799 .497 & 1.572 .458 & 12825 & 998.800 & 3.024 .700 & 1.048 .900 \\
2015 & 4.465 .931 & 40.180 .413 & 1.926 .173 & 2960 & 1.015 .900 & 942.133 & 1.006 .500 \\
\hline
\end{tabular}

\subsection{Analisis Korelasi Setiap Sektor Perikanan}

Untuk menunjukkan korelasi dari masing-masing sektor dengan jumlah hasil produksi akan diuji menggunakan pengujian spearman's rho dengan tingkat signifikansi $(\alpha)=0,05$. Berdasarkan output yang diperoleh dari pengolahan data 
menggunakan SPSS 16.0 bahwa nilai $p$-value yang diperoleh adalah sebagai berikut:

Tabel 3. Tabel Korelasi

\begin{tabular}{lcc}
\hline & Koefisien Korelasi & P-Value \\
\hline Tambak & -.400 & 0,505 \\
Sawah Tambak & 0,500 & 0,391 \\
Kolam & 0,900 & 0,37 \\
KJA & 0,308 & 0,614 \\
Rawa &,- 300 & 0,624 \\
Waduk & 0,200 & 0,747 \\
Sungai &,- 400 & 0,505 \\
\hline
\end{tabular}

Berdasarkan tabel diatas diperoleh bahwa semua nilai p-value untuk semua sector nilainya lebih besar dari 0,05 , sehingga $\mathrm{H}_{0}$ diterima artinya terdapat korelasi antara semua sector terhadap penentuan jumlah hasil produksi ikan konsumsi dikabupaten lamongan.

\subsection{Uji Normalitas dan Uji Friedman Hasil Produksi Ikan Konsumsi}

Uji normalitas jumah hasil produksi ikan konsumsi menggunakan SPSS 16.0 dengan tingkat signifikansi $(\alpha)=0,05$ dan hipotesis $\mathrm{H}_{0}$ menunjukkan populasi jumlah hasil produksi ikan konsumsi berdistribusi normal sedangkan $\mathrm{H}_{1}$ menunjukkan populasi jumlah hasil produksi ikan konsumsi tidak berdistribusi normal. Hasil yang diperoleh yaitu nilai p-value $>0,05$ dari ketujuh sektor. Artinya $\mathrm{H}_{0}$ diterima, jadi populasi jumlah hasil produksi ikan konsumsi tersebut berdistribusi normal.

Selanjutnya data tersebut bisa dilakukan pengujian menggunakan friedman test. Uji Friedman pada data hasil produksi ikan konsumsi menggunakan SPSS 16.0 dengan tingkat signifikansi $(\alpha)=0,05$ dan hipotesis $\mathrm{H}_{0}$ menunjukkan ketujuh sektor perikanan memiliki mutu yang sama sedangkan $\mathrm{H}_{1}$ menunjukkan ketujuh sektor perikanan memiliki mutu yang berbeda. Hasil yang diperoleh yaitu nilai pvalue $=0,000$ menunjukkan bahawa $p$-value $<$ taraf signifikan $(0,000<0,05)$ maka $\mathrm{H}_{0}$ ditolak. Artinya $\mathrm{H}_{1}$ yang diterima, jadi ketujuh sektor perikanan memiliki mutu yang berbeda. Adapun perbedaan mutu dari ketujuh sektor perikanan tersebut disebabkan perbedaan tingkat pengaruhnya dengan jumlah total hasil produksi pada setiap tahun, dengan sampel tahun 2013, 2014, 2015, 2016, dan 2017.

\subsection{Analisis Kecamatan Terpotensial}

Sektor tambak

Berdasarkan analisis data diperoleh bahwa nilai maksimum atau produksi terbesar ikan konsumsi tambak adalah:

a) Tahun $2013=2.307 .096$, yakni kecamatan Brondong

b) Tahun $2014=1.678 .789$, yakni kecamatan Brondong

c) Tahun $2015=1.665 .016$, yakni kecamatan Glagah

d) Tahun $2016=2.471 .691$, yakni kecamatan Brondong 
e) Tahun $2017=2.899 .302$, yakni kecamatan Brondong

Dari 27 kecamatan yang ada dikabupaten lamongan berdasrkan analisis deskriptif statistik diperoleh 2 kecamatan yang selalu unggul dalam produksi ikan konsumsi tambak.

Sektor sawah tambak

Berdasarkan analisis data diperoleh bahwa nilai maksimum atau produksi terbesar ikan konsumsi tambak adalah:

a) Tahun $2013=7387555$, yakni kecamatan Glagah

b) Tahun $2014=5979869$, yakni kecamatan Glagah

c) Tahun $2015=7573528$, yakni kecamatan Karangbinangun

d) Tahun $2016=6061072$, yakni kecamatan Turi

e) Tahun $2017=7272800$, yakni kecamatan Turi

Dari 27 kecamatan yang ada dikabupaten lamongan berdasrkan analisis deskriptif statistik diperoleh 3 kecamatan yang selalu unggul dalam produksi ikan konsumsi sawah tambak.

Sektor kolam

Berdasarkan analisis data diperoleh bahwa nilai maksimum atau produksi terbesar ikan konsumsi tambak adalah:

a) Tahun $2013=462531$, yakni kecamatan Turi

b) Tahun $2014=426098$, yakni kecamatan Turi

c) Tahun $2015=9339962$, yakni kecamatan Turi

d) Tahun $2016=154929$, yakni kecamatan Paciran

e) Tahun $2017=411802$, yakni kecamatan Turi

Dari 27 kecamatan yang ada dikabupaten lamongan berdasrkan analisis deskriptif statistik diperoleh 2 kecamatan yang selalu unggul dalam produksi ikan konsumsi kolam.

Sektor keramba jaring apung

Berdasarkan analisis data diperoleh bahwa nilai maksimum atau produksi terbesar ikan konsumsi tambak adalah:

a) Tahun $2013=0$, yakni tidak ada hasil produksi

b) Tahun $2014=0$, yakni tidak ada hasil produksi

c) Tahun $2015=3470$, yakni kecamatan Karanggeneng

d) Tahun $2016=9301$, yakni kecamatan Karanggeneng

e) Tahun $2017=1725$, yakni kecamatan Laren

Dari 27 kecamatan yang ada dikabupaten lamongan berdasrkan analisis deskriptif statistik diperoleh 2 kecamatan yang selalu unggul dalam produksi ikan konsumsi keramba jarring apung.

Sektor rawa

Berdasarkan analisis data diperoleh bahwa nilai maksimum atau produksi terbesar ikan konsumsi tambak adalah:

a) Tahun $2011=683332$, yakni kecamatan Laren

b) Tahun $2012=675020$, yakni kecamatan Laren

c) Tahun $2013=630433$, yakni kecamatan Laren

d) Tahun $2014=474686$, yakni kecamatan Laren 
e) Tahun $2015=709097$, yakni kecamatan Laren

Dari 27 kecamatan yang ada dikabupaten lamongan berdasrkan analisis deskriptif statistik diperoleh 1 kecamatan yang selalu unggul dalam produksi ikan konsumsi rawa.

Sektor waduk

Berdasarkan analisis data diperoleh bahwa nilai maksimum atau produksi terbesar ikan konsumsi tambak adalah:

a) Tahun $2013=242022$, yakni kecamatan Sugio

b) Tahun $2014=257150$, yakni kecamatan Sugio

c) Tahun $2015=291892$, yakni kecamatan Sugio

d) Tahun $2016=253929$, yakni kecamatan Sugio

e) Tahun $2017=257273$, yakni kecamatan Sugio

Dari 27 kecamatan yang ada dikabupaten lamongan berdasrkan analisis deskriptif statistik diperoleh 1 kecamatan yang selalu unggul dalam produksi ikan konsumsi waduk.

Sektor sungai

Berdasarkan analisis data diperoleh bahwa nilai maksimum atau produksi terbesar ikan konsumsi tambak adalah:

a) Tahun $2013=330048$, yakni kecamatan Sekaran

b) Tahun $2014=299100$, yakni kecamatan Sekaran

c) Tahun $2015=310488$, yakni kecamatan Sekaran

d) Tahun $2016=272771$, yakni kecamatan Sekaran

e) Tahun $2017=279575$, yakni kecamatan Sekaran

Dari 27 kecamatan yang ada dikabupaten lamongan berdasrkan analisis deskriptif statistik diperoleh 1 kecamatan yang selalu unggul dalam produksi ikan konsumsi sawah tambak.

\section{Kesimpulan}

Berdasarkan analisis yang telah dilakukan, diperoleh kesimpulan sebagai berikut:

1. Ketujuh sektor perikanan (tambak, sawah tambak, kolam, keramba jaring apung (KJA), rawa, waduk, sungai) memiliki mutu yang berbeda dalam produksi ikan konsumsi.

2. Dari nilai maksimum hasil produksi sektor yang paling unggul dalam produksi ikan konsumsi yakni budidaya kolam, dan yang terendah adalah budidaya keramba jaring apung.

3. Prosentase pengaruh setiap sektor terhadap jumlah total hasil produksi ikan konsumsi di kabupaten Lamongan yaitu tambak $(-, 400)$; sawah tambak $(0,500)$; kolam $(0,900)$; keramba jaring apung $(0,308)$; rawa $(-, 300)$; waduk $(0,200)$; sungai $(-, 400)$

4. Kecamatan terpotensial dalam produksi ikan konsumsi, yaitu Kecamatan Glagah, Karamgbinangun dan Turi. 


\section{Daftar Pustaka}

[1] A. Rohmatullah, D. Rahmalia, and M. S. Pradana, "Klasterisasi Data Pertanian di kabupaten Lamongan Menggunakan Algoritma K-Means Dan Fuzzy C Means," J. Ilm. Teknosains, vol. 5, no. 2, pp. 86-93, 2019.

[2] M. S. Pradana, D. Rahmalia, and E. D. A. Prahastini, "Peramalan Nilai Tukar Petani kabupaten Lamongan dengan Arima," J. Mat., vol. 10, no. 2, pp. 91-104, 2020.

[3] B. P. Statistik, "Konsep Perikanan," 2020. [Online]. Available: https://www.bps.go.id/subject/56/perikanan.html.

[4] L. S. Atmaja, "Statistika untuk bisnis dan ekonomi," Yogyakarta Penerbit Andi, 2009.

[5] J. Supranto, "Statistik: Teori dan Aplikasi, Jilid 1," 1987. 